\title{
IMPACT OF INTELLIGENT TRANSPORTATION SYSTEMS ON ROAD TRAFFIC SAFETY
}

\author{
Tomasz Szczepanik ${ }^{1}$, Petr Besta ${ }^{2}$ \\ ${ }^{1}$ Czestochowa University of Technology, Faculty of Management \\ ${ }^{2}$ Technical University of Ostrava, Faculty of Metallurgy and Materials Engineering
}

\begin{abstract}
The aim of this paper is to present intelligent transportation systems (ITS) as an element supporting the transportation system which have impact on road traffic safety. The paper presents the role of intelligent transportation systems and tools included in these systems. The areas of application of intelligent transportation systems and the benefits of using these systems were brought closer to the reader. The ITS tasks that influence safety were characterized while emphasizing that one of the basic factors that affect road traffic safety is building and maintaining a safe road infrastructure supported by an ITS. The paper compares and analyses the length of public roads and evaluates their condition, traffic collisions, and fatalities on the basis of the statistical data from the General Directorate for National Roads and Motorways and from Statistics Poland. The Intelligent Road Traffic Control System of the Podhale Region was also discussed as an example of the increase in road traffic safety.
\end{abstract}

Keywords: road traffic safety, Intelligent Transportation Systems, transportation system

DOI: $10.17512 /$ znpcz.2018.1.17

\section{Introduction}

With the continuous increase in the number of vehicles in urban arteries, the constantly improving road infrastructure is insufficient to ensure an adequate level of comfort for road users (Gostkowska-Dźwig, Mrozik 2017, p. 159). This, in turn, affects the increasing importance of road traffic manifested in its structure and dynamics of development. In comparison to other modes of transport of people and goods, road transport has played a key role as one of the leading economic sectors in Poland in the last years. However, with too slow extension of urban roads or even impossible or uneconomical extension in certain urban agglomerations, the development of cities can be inhibited (Pabian 2017, p. 87-88). The frequently implemented solutions aimed at improving safety by closing sections of roads or reducing speed limits (Nowakowska-Grunt, Chłąd, Sośniak 2017, p. 79) lead to a direct or indirect loss in the sector because of the reduced efficiency.

\section{Description of Intelligent Transportation Systems}

The transport system has always played a significant role in the economic and social life of people while determining the technological advances and development of modern civilization. However, transport also leads to negative results in social 
areas, especially through fatalities in traffic collisions (Nowicka 2014, p. 110). Contemporary transport systems should be balanced (Brzozowska, Grabińska, Imiołczyk 2017, p. 56-58). Therefore, both the conditions of the development of transport networks and the implementation of modern tools that are aimed at facilitating their management are examined (Kot, Marczyk, Ślusarczyk 2014, p. 273-275).

The problems of intelligent transport systems (ITS) belong to the most extensively explored areas concerned with the functioning and results of transport. ITSs are systems which represent a variety of technologies: information, telecommunication, automation and measurement technologies (Brzozowska, Zacharski 2015, p. 262) integrated in order to provide innovative services that relate to the various types of transport and management of road traffic. In this way, ISTs ensure the safety and mobility of passengers and goods, improve the standard of transport services and increase the effectiveness of the entire transport system in the city (including the reduction of operating costs and improved competitiveness of the city). At the same time they help reduce the degradation of the natural environment (Nowicka 2014, p. 93). The term Intelligent Transportation System was first defined in 1994 at the world congress in Paris concerning transportation systems. Intelligent Transportation Systems are defined as a systems that represent a broad selection of various technologies and techniques used for transport and management. They are aimed at ensuring the safety of road users and improving the efficiency of the transport system while protecting environmental resources. As an alternative to this name, ISO proposed the abbreviation RTTT (Road Traffic and Transport Telematics).

Intelligent transport systems allow for, e.g., traffic control, the creation of special zones of limited traffic and reduction of carbon dioxide emissions through activities aimed at reducing the number of private cars in city centres. ITSs, based on modern technological and organizational solutions for transport, belong to the most efficient instruments to improve the efficiency and quality of the transport system in cities (MTBiGM 2013).

One of the major components of the intelligent transport infrastructure is intelligent transportation systems. Among other things, they allow for:

- efficient support to ensure protection and safety of transport users,

- reduction of a negative impact of transport on the environment,

- increased efficiency of transport processes that affect the development of the transport sector with consideration for contemporary tendencies and capabilities of information and communications technology (see: Bazzan, Klüg 2014, p. 38).

- The benefits of using intelligent transportation systems in these areas include:

- traffic capacity of streets higher by $20-25 \%$,

- increased road traffic safety (reduced number of collisions by $40-80 \%$ ),

- reduced travelling time and energy consumption (by 45-70\%),

- improved convenience of travelling and traffic conditions for drivers,

- passengers of public transportation and pedestrians,

- reduction of costs of road vehicle fleet management,

- reduction of costs of road surface maintenance and renovation, 
- improved quality of the natural environment (reduction of flue gas emissions by $30 \%$ to $50 \%$ ),

- increased economic benefits in the region (Litwin, Oskarbski, Jamroz 2006, p. 167-174).

Thanks to implementing ITSs it is possible to use the current infrastructure in a more effective, economical and safe way.

\section{Improved safety through the use of ITS}

In practice, ITSs affect all elements that determine the service capabilities of transport. It is worth emphasizing the problems of transport system organization, its operating capability, and resistance to random events. The tasks of the traffic management system on the part of the road supported by an ITS are:

- controlling the speed of vehicles that move on the road to eliminate the vehicles that exceed permissible speed, which has a negative influence on traffic smoothness and safety, e.g., speed cameras,

- maintaining the speed on the road below the maximum permissible levels to maximize traffic capacities in sections of specific traffic intensity and traffic concentration,

- controlling the level of road traffic concentration by redirecting excess vehicles to alternative routes,

- eliminating factors that can limit average vehicle speed and generate threat to human safety by detecting road incidents, monitoring the condition of the road surface, e.g., removing snow,

- informing about difficult road conditions (for more details see: Matczak 2014, p. 262-320).

Therefore, ITSs can warn drivers that some dangers can occur (e.g., glaze, traffic jams, traffic collisions) using electronic boards on which announcements with changing content can be displayed. These are most often mandatory signs (e.g., dynamic change in permissible speed), prohibition signs (e.g., control of overtaking) or warning signs (fog, collisions, etc.). The examination of traffic on German motorways confirms the high efficiency of such systems. With these systems, a $25 \%$ reduction in the total number of traffic collisions was observed, and, in the case of multiple vehicle collisions (at least 5 vehicles), the reduction was even $54 \%$. Nearly $80 \%$ of collisions caused by fog were also eliminated (Piszczek 2008, p. 76).

Building and maintaining a safe traffic infrastructure required by the ITS is one of the basic factors in road traffic safety (Komornicki et al. 2013, p. 91-99). Concluding on the correlations between the expenditure on transport infrastructure, including ITS (Węclawowicz et al. 2006), and the level of safety is difficult due to the complexity of the phenomenon. It is also indicated that the road and its environment have a significant impact on $28-35 \%$ of the risk of injuries, whereas motorways and expressways are responsible for the smallest number of road victims (Eurorap 2017). Table 1 presents the length of public roads in Poland in 2010-2015. 
Table 1. Length of public roads in Poland in 2010-2015

\begin{tabular}{|c|r|r|r|r|r|r|}
\hline Period & \multicolumn{1}{c|}{$\mathbf{2 0 1 0}$} & \multicolumn{1}{c|}{$\mathbf{2 0 1 1}$} & \multicolumn{1}{c|}{$\mathbf{2 0 1 2}$} & \multicolumn{1}{c|}{$\mathbf{2 0 1 3}$} & \multicolumn{1}{c|}{$\mathbf{2 0 1 4}$} & \multicolumn{1}{c|}{$\mathbf{2 0 1 5}$} \\
\hline $\mathbf{k m}$ & 406122.1 & 412263.7 & 412035.1 & 413529.8 & 417026.0 & 419636.4 \\
\hline $\begin{array}{c}\text { per } \\
\mathbf{1 0 0} \mathbf{~ k m}^{2}\end{array}$ & 129.9 & 131.8 & 131.8 & 132.3 & 133.4 & 134.2 \\
\hline
\end{tabular}

Source: Author's own elaboration based on the data obtained from the Central Statistical Office: Transport - wyniki działalności (GUS 2011-2016)

The data presented in Table 1 reveal that the number of public roads in Poland increased dynamically in the period of the study, including hard surface roads. An important division used to describe road infrastructure is the categorization of roads which leads to the delegation of responsibility for maintaining and developing individual sections of the infrastructure. Based on this criterion, there are four types of road connections and the respective responsible authorities:

- national roads $(19292.8 \mathrm{~km})$ - the General Directorate for National Roads and Motorways,

- voivodeship roads $(29108.6 \mathrm{~km})$ - the competent voivodeship marshals,

- powiat roads $(125092.3 \mathrm{~km})$ - the competent starostas or city presidents,

- gmina roads $(246142.7 \mathrm{~km})$ - the mayors of towns or rural communes.

It can be added that national roads, which accounted for $4.6 \%$ of connections in Poland, cover ca. 60\% of total road traffic in Poland and most traffic collisions occur on this type of roads (MI 2011). Per $100 \mathrm{~km}$ of motorways and expressways in Poland in 2015, the number of traffic collisions was 17.4, with the number of fatalities of 3.2, whereas for other national roads these numbers were 215.1 and 20.3 , i.e., several times more. Furthermore, despite the unprecedented increase in the contribution of motorways and expressways in the total length of national roads in 2004-2015 from $4.3 \%$ to $12.9 \%$, the percentage of collisions on these roads in accidents in total increased insignificantly from $0.6 \%$ to $1.1 \%$, whereas for fatalities, this increase was from $1.2 \%$ to $2.3 \%$ (for more details see: Komornicki et al. 2013, p. 92).

According to the report on the technical condition of the national road network as of the end of 2015, the percentage of road surface in good condition was $60.6 \%$ of the total length of the national road network. Furthermore, poor condition was found for $14.1 \%$ of the total length of the national road network. Importantly, the structure of technical quality of the national road network is gradually improving, as shown in Table 2. 
Table 2. Percentage distribution of the evaluation of the condition of national roads in 2010-2017

\begin{tabular}{|c|r|r|r|r|r|r|r|r|}
\hline & $\mathbf{2 0 1 0}$ & $\mathbf{2 0 1 1}$ & $\mathbf{2 0 1 2}$ & $\mathbf{2 0 1 3}$ & $\mathbf{2 0 1 4}$ & $\mathbf{2 0 1 5}$ & $\mathbf{2 0 1 6}$ & $\mathbf{2 0 1 7}$ \\
\hline $\begin{array}{c}\text { Good } \\
\text { condition }\end{array}$ & 59.1 & 58.8 & 62.7 & 66.1 & 61.7 & 60.6 & 53.7 & 58.1 \\
\hline $\begin{array}{c}\text { Unsatisfactory } \\
\text { condition }\end{array}$ & 22.0 & 23.6 & 23.8 & 21.4 & 25.1 & 25.3 & 30.2 & 26.0 \\
\hline $\begin{array}{c}\text { Poor } \\
\text { condition }\end{array}$ & 18.9 & 17.6 & 13.5 & 12.5 & 13.2 & 14.1 & 16.1 & 14.5 \\
\hline
\end{tabular}

* $1.4 \%$ - non-aggregate data, roads in repair and rebuilding ${ }^{1}$

Source: Author's own elaboration based on the data obtained from the General Directorate for National Roads and Motorways: Report on the state of national roads (GDDKiA 2011-2017)

Good condition of roads defined as the desired state is defined by the General Directorate for National Roads and Motorways (GDDKiA) as "new, repaired and used road surfaces where permissible damages do not require taking any measures. The road with unsatisfactory condition means the warning level where the road surface is characterized by damages which require repairs. Furthermore, poor condition means a critical level, with road surface that needs taking immediate repair works". (GDDKiA 2016). However, apart from the road surface condition, the key role is played by the road system management and the tools used for this purpose, which reduce the number of traffic collisions and fatalities, as presented in Table 3.

Table 3. Traffic collisions and fatalities due to the collisions in Poland in 2010-2016

\begin{tabular}{|c|c|c|c|c|c|c|c|}
\hline & $\mathbf{2 0 1 0}$ & $\mathbf{2 0 1 1}$ & $\mathbf{2 0 1 2}$ & $\mathbf{2 0 1 3}$ & $\mathbf{2 0 1 4}$ & $\mathbf{2 0 1 5}$ & $\mathbf{2 0 1 6}$ \\
\hline $\begin{array}{c}\text { Traffic } \\
\text { collisions }\end{array}$ & 38832 & 40131 & 37062 & 35847 & 34970 & 32967 & 33664 \\
\hline $\begin{array}{c}\text { Fatalities due } \\
\text { to traffic } \\
\text { collisions }\end{array}$ & 3907 & 4189 & 3571 & 3357 & 3202 & 2938 & 3026 \\
\hline
\end{tabular}

Source: Author's own elaboration based on the data obtained from the Central Statistical Office: Transport - wyniki działalności (GUS 2011-2016)

The highest percentage of fatalities in Poland (over 33\%) were caused by traffic collisions connected with driving into pedestrians on the road, which is the index that distinguishes Poland from Europe and even the world (Przybyłowski 2014,

1 The sections of the roads under repair and many-year rebuilding works, with secure financing (signed contracts). The works were started in 2017 or before, whereas their completion is planned for 2018 or later. The total length of the road sections included few cases of sections with missing data. In the document, the data for such roads are defined as non-aggregate data or roads under repair. 
p. 33). A high level of fatalities (15-20\%) is also generated in head-on crashes, whose frequent cause is the lack of divided lanes. Similarly dangerous are side collisions connected with traffic collisions on intersections and at their entries and exits and collisions with obstacles (trees, posts) located too close to the road edge, with their cause being, among other things, the lack of movement control systems on intersections. Cyclists represent $8 \%$ of fatalities, which is merely $1 \%$ share in the road traffic (NIK 2016). The number of road victims among motorcyclists and moped users is also increasing. As the data show, implementing ITSs in order to prevent traffic incidents and improve safety should become a priority in the management of city road systems.

\section{The Intelligent Road Traffic Control System of the Podhale Region as an example of the increase in road traffic safety}

An example of ensuring safety by implementing an ITS is the Podhale region of Poland. Road traffic safety on all analysed roads which are in the Intelligent Road Traffic Control System of the Podhale Region (ISSRRP) was assessed positively. A decline in the number of traffic collisions was noted (by $45 \%$ compared to the period before the system implementation). Before the implementation, 696 bumps and 152 accidents had been recorded on the voivodeship roads. In these events, 7 people were dead, and 163 injured. In the period of system implementation on the voivodeship roads, the number of bumps was reduced by $42 \%$, number of accidents by $58 \%$, number of injured by $45 \%$, and number of fatalities by $42 \%$. After the implementation of the ISSRRP, a substantial decline in the causes connected with various types of collisions was found, which demonstrates that, on the one hand, traffic dissipation improves traffic conditions, that is, traffic has become smoother ("Polskie Drogi" 2014). On the other hand, the driver is informed about the possibility of this choice, which can also reduce aggressive behaviours of drivers and, therefore, aggressive driving.

It can be concluded that a broad range of opportunities for using ITSs to improve the functioning of vehicle traffic brings numerous benefits, including improved road safety. Compensating for the negative effects such as congestion or environmental protection is, besides ensuring safety to potential beneficiaries, the value in itself, but these components have an indirect effect on the higher level of road safety where an ITS was used.

\section{Conclusions}

The implementation of ITSs is aimed at reducing the number of traffic collisions and improving road safety by using:

- speed cameras: safety improved by $80 \%$,

- traffic control at entries to expressways: increase in safety of up to $50 \%$,

- advanced traffic control systems: increase in safety by up to $80 \%$,

- random event management systems: increase in safety by up to $50 \%$ (Koźlak 2008, p. 4). 
Comparing the effects of implementing ITS in the transport system to the historical data about the number of traffic collisions and fatalities leads to the conclusion that transport management with ITS tools will substantially increase the level of safety. Reducing the number of collisions and, consequently, the number of fatalities and injured, will be the biggest non-financial benefit for road users.

The increase in traffic capacity of the streets due to the use of:

- traffic management systems on expressways: up to $25 \%$ greater traffic capacity,

- systems of redirecting vehicles to alternative routes by signs with changing contents: up to $22 \%$ greater traffic capacity (Litwin, Oskarbski, Jamroz 2006, p. 167-174),

also leads to higher safety of road users (Wojewódzka-Król, Rolbiecki 2010, p. 70). Greater traffic capacity of streets allows rescue teams and police to get to victims faster during traffic collisions.

The improved effectiveness of rescue teams due to:

- road event management systems and rescue teams results in shortening the time of event detection by up to $66 \%$,

- shortening the time needed to get to the collision site by rescue teams by up to $43 \%$,

- using systems of automated localization of rescue vehicles and navigation to the collision site: shortening the time needed to reach the site by up to $40 \%$ (Koźlak 2008, p. 4).

These tools will allow for a faster response and getting adequate rescue teams to collision sites while having a positive effect on the improved road user safety.

Improved road safety due to the reduction in the number of collisions by:

- using speed cameras that improve road safety of up to $80 \%$,

- implementing traffic control at entries to expressways improves safety by up to $50 \%$,

- advanced systems of traffic control which allow for the increase in safety of up to $80 \%$,

- using random event management systems which help to improve road safety by up to $50 \%$ (Koźlak 2008, p. 4).

The development of road networks is a key factor in road safety. However, without management systems supported by ITSs, it will be only an element of infrastructure used for transport of goods and persons. The use of ITSs allows for increasing the number of cases by $40 \%$ to $80 \%$ (Koźlak 2008, p. 4). The problem of ensuring safety and continuous improvement of its level is one of the major factors in the implementation of ITS tools and benefits that result from their application.

The impact of ITSs on safety in the transport system should be assessed after the introduction of these systems and, if possible, selected parameters in individual cities, when the implemented systems have the same or similar functionalities. The example of the Intelligent Traffic Control System of the Podhale region shows a large drop in the number of collisions and accidents, and hence the number of wounded and fatalities. It is a real increase in road safety through the implementation of ITS. 


\section{Literature}

1. Bazzan A.L.C., Klügl F. (2014), Introduction to Intelligent Systems in Traffic and Transportation, Morgan \& Claypool, USA.

2. Brzozowska A., Grabińska A., Imiołczyk J. (2017), Informatyzacja jako element zrównoważonego rozwoju kraju, "Zeszyty Naukowe Politechniki Częstochowskiej. Zarządzanie”, nr 23, t. 1, p. 56-64. DOI: 10.17512 /znpcz.2016.3.1.06

3. Brzozowska A., Zacharski J. (2015), Telematics in Agricultural Machinery, [in:] Brzozowska A., Kalinichenko A. (eds.), Transformation Management of Economics at Rural Areas, Poltava State Agrarian Academy, Poltava, p. 261-268.

4. European Communities (2004), Planning a Modern Transport System. A Guide to Intelligent Transport System Architecture, FRAME-IST.

5. Eurorap (2017), Europejski Program Oceny Ryzyka na Drogach, http://www.eurorap.pl/ (accessed: 21.06.2017)

6. GDDKiA (2011-2017), Raport o stanie technicznym nawierzchni sieci dróg krajowych, Generalna Dyrekcja Dróg Krajowych i Autostrad, Warszawa.

7. Gostkowska-Dźwig S., Mrozik M. (2017), Determinanty rozwoju jakości sektora ustug transportu miejskiego $w$ Czestochowie $w$ aspekcie mobilności jej mieszkańców, „Zeszyty Naukowe Politechniki Częstochowskiej. Zarządzanie”, nr 26, p. 158-166. DOI: 10.17512/ znpcz.2017.2.14

8. GUS (2011-2016), Transport - wyniki działalności, Główny Urząd Statystyczny, Warszawa.

9. Komornicki T., Rosik P., Śleszyński P., Solon J., Wiśniewski R., Stępniak M., Czapiewski K., Goliszek S., Regulska E. (2013), Wpływ budowy autostrad i dróg ekspresowych na rozwój społeczno-gospodarczy $i$ terytorialny Polski, Ministerstwo Rozwoju Regionalnego, Warszawa.

10. Kot S., Marczyk B., Ślusarczyk B. (2014), Identifications of Information Systems Application in Road Transport Companies in Silesia Region, [in:] Telematics - Support for Transport. 14th International Conference on Transport Systems Telematics, TST 2014, Katowice/Kraków/Ustroń, Poland, October 22-25, 2014. Selected Papers, Communications in Computer and Information Science Vol. 471, Springer-Verlag, Berlin, Heidelberg, p. 273-283.

11. Koźlak A. (2008), Inteligentne systemy transportowe jako instrument poprawy efektywności transportu, „Logistyka”, nr 2.

12. Litwin M., Oskarbski J., Jamroz K. (2006), Inteligentne Systemy Transportu - Zaawansowane Systemy Zarzadzania Ruchem, [in:] I Polski Kongres Drogowy "Lepsze drogi-lepsze życie". Papers, 1st Polish Road Congress "Better roads - better life": proceedings, Polski Kongres Drogowy, Warszawa, p. 167-174.

13. Matczak M. (2014), Wykorzystanie inteligentnych systemów transportowych (ITS) w optymalizacji wykorzystania infrastruktury transportu, [in:] Grzelakowski A.S., Matczak M. (red.), Infrastruktura transportu. Wspótczesne wyzwania rozwojowe, IMP, Gdańsk, p. 262-320.

14. MI (2011), Program Budowy Dróg Krajowych na lata 2011-2015, Ministerstwo Infrastruktury, Warszawa, http://www.transport.gov.pl/files/0/1793723/Program20112015.pdf (accessed: 21.06.2014).

15. MTBiGM (2013), Strategia rozwoju transportu do 2020 roku (z perspektywa do 2030 roku), Ministerstwo Transportu, Budownictwa i Gospodarki Morskiej, Warszawa, https://www.mir.gov.pl/media/3511/Strategia_Rozwoju_Transportu_do_2020_roku.pdf (accessed: 25.05.2015)

16. NIK (2016), NIK o bezpieczeństwie pieszych i rowerzystów na drogach publicznych, Przegląd ITS, ITS, Polska 2016.

17. Nowakowska-Grunt J., Chłąd M., Sośniak S. (2017), Logistics in the City Management System, "Zeszyty Naukowe Politechniki Częstochowskiej. Zarządzanie", nr 27, t. 2, p. 78-86. DOI: 10.17512/znpcz.2017.3.2.08 
18. Nowicka K. (2014), Inteligentne systemy transportowe a zarzadzanie miastem, [in:] Bryx M. (red.), Innowacje w zarzadzaniu miastami w Polsce, Oficyna Wydawnicza SGH, Warszawa, p. 92-110.

19. Pabian A. (2017), Logistics Infrastructure of Motorways in Sustainable Development of a Region, "Zeszyty Naukowe Politechniki Częstochowskiej. Zarządzanie”, nr 27, t. 2, p. 87-95. DOI: 10.17512/znpcz.2017.3.2.09

20. Piszczek S. (2008), Systemy zarzadzania ruchem w Niemczech, I Kongres ITS, Warszawa.

21. "Polskie Drogi" (2014), Bezpieczeństwo ruchu drogowego i inteligentne systemy transportowe, "Polskie Drogi", nr 7-8, bezpłatny dodatek do miesięcznika.

22. Przybyłowski A. (2014), Wypadki drogowe i ich skutki w polskich regionach na tle tendencji europejskich, "Logistyka", nr 3, p. 5338-5346.

23. Węcławowicz G., Bański J., Degórski J., Komornicki T., Korcelli P., Śleszyński P. (2006), Przestrzenne zagospodarowanie Polski na poczatku XXI wieku, IGiPZ PAN, Warszawa, http://rcin.org.pl/Content/2270/WA51_13507_r2006-nr6_Monografie.pdf (accessed: 21.06.2014).

24. Wojewódzka-Król K., Rolbiecki R. (2010), Inteligentne systemy transportowe w świetle europejskiej polityki transportowej, "Zeszyty Naukowe Uniwersytetu Szczecińskiego. Ekonomiczne Problemy Usług”, nr 57, p. 65-72.

\section{WPŁYW INTELIGENTNYCH SYSTEMÓW TRANSPORTOWYCH NA BEZPIECZEŃSTWO}

Streszczenie: Celem artykułu jest przedstawienie inteligentnych systemów transportowych jako elementu wspomagającego system transportowy, co wpływa na bezpieczeństwo na drogach. W artykule zaprezentowano istotę inteligentnych systemów transportowych oraz narzędzia wchodzące $w$ ich skład. Przybliżono zakres zastosowania inteligentnych systemów transportowych oraz omówiono korzyści wynikające z ich zastosowania. Scharakteryzowano zadania ITS mające wpływ na kwestie bezpieczeństwa, jednocześnie podkreślając, iż jednym z podstawowych czynników wpływających na bezpieczeństwo ruchu jest budowa i utrzymanie bezpiecznej infrastruktury drogowej wspomaganej przez ITS. W artykule dokonano zestawienia i analizy długości dróg publicznych, oceny ich stanu oraz wypadków i ofiar śmiertelnych. Omówiono także Inteligentny System Sterowania Ruchem Regionu Podhalańskiego jako przykład wzrostu bezpieczeństwa.

Słowa kluczowe: bezpieczeństwo, inteligentne systemy transportowe, system transportowy 